\title{
JURIS PRUDENCE: CALABRESI'S UNEASY RELATIONSHIP WITH THE COASE THEOREM
}

\author{
STEVEN G. MEDEMA*
}

INTRODUCTION

If the published record is any indication, Guido Calabresi's association with the Coase theorem is nearly as old as Coase's own. Indeed, an argument could be made, judging by how the literature on the theorem has evolved, that Calabresi "discovered" the Coase theorem roughly two years before Coase first stated these ideas in print. What is incontrovertible is that Calabresi has devoted far more words to discussion of the theorem than did Coase, though this is an easy mark given that Coase had almost nothing to say on the subject after 1961-at least until taking some pains in a 1988 collection of his most significant articles to explain what he was on about in The Problem of Social Cost $^{1}$ and how all of the attention paid to the theorem represented a misunderstanding of his message. ${ }^{2}$ Among legal scholars, few have referenced Coase's negotiation result more often than has Calabresi, and perhaps no one has probed its implications so deeply. ${ }^{3}$

\section{Copyright $(\odot 2014$ by Steven G. Medema.}

This article is also available at http://lcp.law.duke.edu/.

* Distinguished Professor of Economics, University of Colorado Denver. I wish to thank Guido Calabresi, Pierre Schlag, the editors of this issue of Law and Contemporary Problems, two anonymous referees, and participants in the Prague conference in honor of Guido Calabresi's 80th birthday for insightful comments on this discussion. The support of the Institute for New Economic Thinking and the National Endowment for the Humanities is gratefully acknowledged.

1. 3 J.L. \& ECON. 1 (1960) [hereinafter Coase, The Problem of Social Cost].

2. See R.H. CoAse, Notes On the Problem Of Social Cost, in The Firm, THE MARKeT, AND THE LAW 157 (1988) [hereinafter COASE, Notes]. Coase's two pre-1988 commentaries are R.H. Coase, Social Cost and Public Policy, in EXPLORING THE FrontIERS OF ADMINISTRATION: SIX ESSAYs FOR MANAGERS 33 (George A. Edwards ed., 1970), in which he simply restates in summary form the major conclusions of The Problem of Social Cost, and R.H. Coase, The Coase Theorem and the Empty Core: A Comment, 24 J.L. \& ECON. 183 (1981), in which he defends his negotiation result.

3. In this article, I use the terms "Coase theorem" and "Coase's negotiation result" interchangeably, recognizing that the former, although generally associated with the latter, did not appear in the literature until 1966 and did not achieve widespread use until well into the 1970s. See GEORGE J. STIGLER, THE THEORY OF PRICE 113 (3d ed. 1966).

Evidence of the primacy of Calabresi's treatments of Coase comes from the author's database of some 6000 articles referring to the Coase theorem or The Problem of Social Cost. (The database can be approximated via HeinOnline and Jstor searches, on file with Law and Contemporary Problems.) The data suggest that, within the legal literature, only Richard Posner and Robert Cooter have discussed Coase's result more often than has Calabresi. 
The Coase theorem is one of the most controversial ideas to emerge within economics and law over the last half century, and the literature discussing or invoking it runs to some 6000 articles, as well as many hundreds of books. ${ }^{4}$ It is an idea that is in equal turns mystical and infuriating, its beauty-or lack thereof-being in the eye of the beholder. Calabresi's attitude toward the theorem has, over time, oscillated to both of these extremes, and to various points in the middle. Some of this oscillation is an artifact of his own evolving views, while other aspects are a function of the context in which he considered Coase's result. In all of this, though, Calabresi's engagement with Coase's negotiation result provides an interesting window onto the history of the Coase theorem - an idea that played a fundamentally important role in reshaping aspects of both legal and economic analysis in the last third of the twentieth century.

In choosing the subject of this article I have assumed that there is something called the "Coase theorem," and in the title I suggest that Calabresi has had an uneasy relationship with it-whatever it is. The problem is that the Coase theorem admits of no singular definition - a fact that, as it turns out, helps to explain Calabresi's uneasy relationship with it. In fact, his to-and-fro with the Coase theorem is in some ways a microcosm of the theorem's larger history, a subject that lies well beyond the scope of the present article. ${ }^{5}$ If one can, however, speak of a "typical" statement of the Coase theorem, it might go something like this: If transaction costs are zero and property rights over the relevant resources are well-defined, parties involved in an externality situation will bargain to an efficient and invariant resolution, regardless of to whom the property rights are initially assigned. ${ }^{6}$ So stated, the theorem embodies two assumptions and two conclusions. The theorem embodies the assumptions that property rights are well defined and the costs of transacting are zero. The conclusions that emerge are that the resulting allocation of resources will be efficient and that this result will be invariant across alternative assignments of rights. But the theorem has been stated in innumerable ways over the yearswith and without the invariance result, and with various additional assumptions or qualifications - and its scope has been expanded well beyond the simple

4. Id.

5. This article is part of a much larger project in which I trace the intellectual history of the Coase theorem, including its diffusion in the legal literature. See, e.g., Steven G. Medema, 1966 and All That: The Birth of the Coase Theorem Controversy, 36 J. HIST. ECON. THOUGHT (forthcoming Sept. 2014); Steven G. Medema, The Curious Treatment of the Coase Theorem in Environmental Economics, 19601979, 8 REV. ENVTL. ECON. \& POL'Y (forthcoming Winter 2014) (discussing aspects of the Coase theorem's early history in economics and law); Steven G. Medema, Debating Law's Irrelevance: Legal Scholarship and the Coase Theorem in the 1960s (Jan. 29, 2013) [hereinafter Medema, Debating Law's Irrelevance] (unpublished manuscript) (on file with the University of Colorado Denver); Steven G. Medema, Rethinking Externalities: Coase's Negotiation Result Before the Coase Theorem (Apr. 24, 2013) (unpublished manuscript) (on file with the University of Colorado Denver).

6. See Steven G. Medema, The Coase Theorem: Lessons for the Study of the History of Economic Thought, 33 J. HIST. ECON. THOUGHT 1 (2011). 
property-rights solutions initially contemplated by Coase. ${ }^{7}$ Calabresi's various engagements with Coase's result reflect the elusiveness of this target.

In the pages that follow, I will analyze Calabresi's relationship with the idea that has come to be known as the Coase theorem. ${ }^{8}$ Because much of Calabresi's work with the Coase theorem occurred on the front end of the theorem's history, Calabresi was a player in how the Coase-theorem discussion played out in the early years-particularly within law. This early engagement also made him responsible - both directly, through his writings, and indirectly, through his students and others influenced by his writings-for much of the early diffusion of the Coase theorem in legal literature. ${ }^{9}$ Calabresi was a legal scholar with roots in both economics and legal realism who was enamored of the potential power of Coase's result as he (Calabresi) interpreted it-an interpretation in certain ways radically different from Coase's own conception of his negotiation result-even if not convinced of its real-world applicability. Although he initially found in Coase's result the basis for legal-decision criteria that would promote efficient allocations of resources, Calabresi eventually concluded that its true power lay in its implications for the distributional effects of legal rules.

II

\section{THE ACCIDENTAL TOURIST}

The road that took Calabresi to the application of price theory to legal issues - a road that included extensive economics studies - has been related on several occasions by Calabresi himself and so will not be rehearsed here. ${ }^{10}$ Instead, the concern here goes to one facet of how Calabresi's economics training influenced his approach to legal analysis. The initial manifestation of his interest in integrating economics into legal analysis was, of course, Some Thoughts on Risk Distribution and the Law of Torts, originally written as a paper during Calabresi's law school days but not published as an article until $1961 .{ }^{11}$ What the article has to do with the Coase theorem, though, does not admit to a simple answer, in spite of its established place in the Coase-theorem literature. ${ }^{12}$

7. For a litany of statements of the Coase theorem, see id. See also THE COASE THEOREM (Richard A. Posner \& Francesco Parisi eds., 2013) (containing reprints of a substantial number of the most significant articles from the Coase-theorem literature along with an original introduction by Posner and Parisi); Steven G. Medema \& Richard O. Zerbe, Jr., The Coase Theorem, in 1 ENCYCLOPEDIA OF LAW AND ECONOMICS 836 (Boudewijn Bouckaert \& Gerrit De Geest eds., 2000).

8. The subject of Calabresi and the Coase theorem has previously been taken up by Alain Marciano. See Alain Marciano, Guido Calabresi's Economic Analysis of Law, Coase and the Coase Theorem, 32 INT'L REV. L. \& ECON. 110 (2012). The present article is rather differently focused, though it does provide additional insight into certain of the issues raised in Marciano's analysis.

9. See generally Medema, Debating Law's Irrelevance, supra note 5.

10. See, e.g., Guido Calabresi, Neologisms Revisited, 64 MD. L. REV. 736 (2005) [hereinafter Calabresi, Neologisms Revisited].

11. 70 YALE L.J. 499 (1961) [hereinafter Calabresi, Some Thoughts]. The story behind the publication of this article is related in Calabresi, Neologisms Revisited, supra note 10.

12. One perspective on this can be found in Marciano, supra note 8, at 111 (arguing that "the 
Central to Calabresi's 1961 discussion is the claim, from welfare economics, that "the most desirable system of loss distribution under a strict resourceallocation theory is one in which the prices of goods accurately reflect their full cost to society." 13 For Calabresi, the application of the allocative-efficiency criterion to individual torts-interactions thought to violate this efficiency requirement because agents do not bear the full costs associated with their actions-entails that the costs of a harm-causing activity be internalized to the activity causing the harm and that the process of internalization should assign that cost to the party who can best ensure that this cost is reflected in the pricing of the good in question. ${ }^{14}$ This insight, of course, provided the basis for the least cost-avoider rule later advocated by Calabresi in his analysis of tort liability. ${ }^{15}$

Although Calabresi grounded his 1961 article in the claim that economics could, and should, provide the basis for the allocation of accident costs, he made no bones about his sense that, in the determination of the party on whom to place tort liability in order to achieve the desired efficient outcome, "traditional economic theory is of little help." 16 The problem, he said, is that "in the economist's world it often makes no difference whether, for example, the cost of an injury is put on a worker or on his employer." ${ }^{, 17}$ If employers were liable for harm, they would offer their workers wage terms that were correspondingly reduced, whereas if employees were liable, they would demand higher wages to cover the cost of acquiring insurance or of self-insuring. "Either way," said Calabresi, the theory tells us that "the cost would find its way into wages and into prices." 18 Thus, "[f]rom the standpoint of resource allocationsthough perhaps only from that standpoint-nothing would be changed" by assigning liability to one party rather than the other. ${ }^{19}$

The modern reader may be inclined to nod his or her head and conclude that Calabresi had obviously read his Coase and learned his lessons well. But given that Coase's article was published only weeks before Calabresi's article appeared, and that Calabresi likely had no knowledge of Coase's analysis there or in The Federal Communications Commission ${ }^{20}$ at that point, he had almost certainly not learned a thing from Coase. ${ }^{21}$ In fact, the allocative-neutrality result referenced by Calabresi was, as he pointed out, a piece of theory whose

similarities and differences" between the works of Coase and Calabresi "are deeper and more complex" than is generally recognized).

13. Calabresi, Some Thoughts, supra note 11, at 505.

14. Id.

15. See, e.g., Guido CAlabresi, The Costs of AcCidents: A Legal AND ECONOMiC ANALYSIS 135-173 (1970) [hereinafter CALABRESI, COSTS].

16. Calabresi, Some Thoughts, supra note 11, at 505.

17. Id.

18. Id.

19. Id. at $506 \mathrm{n} .25$.

20. 2 J.L. \& ECON. 1 (1959).

21. Coase's article, though bearing a 1960 publication date, did not appear in print until early in 1961. See Edmund W. Kitch, The Fire of Truth: A Remembrance of Law and Economics at Chicago, 1932-1970, 26 J.L. \& ECON. 163, 221 (1983). 
origins antedate Coase's writing by at least a half-century. ${ }^{22}$ In short, Calabresi's proposal of allocative invariance was not anything new, at least to economists; the allocative invariance of alternative specifications of legal liability, as he made clear, was a widely accepted theoretical property of "the economist's world." 23

But Calabresi was not willing to lend a great deal of empirical credence to the economist's world or to the economist's theoretical claims about the invariant effects of alternative liability assignments, labeling previous attempts to apply this theory to the context of workplace accidents "inaccurate." ${ }^{24}$ The problem, he said, is that this theory "presupposes an all knowing, all rational economic world which does not exist." ${ }^{, 25}$ Reality, Calabresi argued, points us in a different direction: Some assignments of risk do not allow for the transfer of the relevant costs into prices ${ }^{26}$ parties may evaluate risk differently, and the rates at which parties are able to insure against risk may differ ${ }^{27}$ Further, each of these factors will cause a variation in prices, and thus incentives, across alternative assignments of liability, thereby giving rise to output and activity levels that vary with the assignment of liability. As such, the determination of liability will tend to impact the efficiency of resource allocation. ${ }^{28}$

That said, Calabresi did allow that there are some situations in which the economist's view of the problem is relevant-that is, "where it actually does not matter who bears the loss initially." ${ }^{29} \mathrm{He}$ cited the utilization of independent contractors and products-liability cases involving commercial buyers and sellers as possible examples, because these may represent situations in which each party is able to allocate the relevant cost to the appropriate activity or product. ${ }^{30}$ Calabresi even allowed that this reasoning might apply to certain modern workers' compensation situations, given the development of strong labor unions

22. Calabresi cited works by economists Frank Taussig of Harvard and Harry Gunnison Brown as representative of the received view. Calabresi, Some Thoughts, supra note 11, at 506 n.23 (citing FRANK W. TAUSSIG, 2 PRINCIPLES OF ECONOMICS 326-27 (1911); Harry Gunnison Brown, The Incidence of Compulsory Insurance of Workmen, 30 J. POL. ECON. 67 (1922)). Taussig's book, of course, was the leading U.S. textbook of the period, and Gunnison Brown made explicit reference in his article to the widely accepted nature of the invariance proposition. See Brown, supra, at 77 (arguing that "[it] will be obvious to the reader" that the costs of insurance against workplace accidents will ultimately fall on the workers "regardless of their imposition . . . initially upon employers."). As George Stigler later noted regarding Coase's result, the same logic was generally seen to apply to a range of laws, perhaps most prominently to the incidence of a sales tax. See STIGLER, supra note 3, at 113.

23. Calabresi, Some Thoughts, supra note 11, at 505.

24. Id. at 506 .

25. Id.

26. For example, making pedestrians liable for auto-pedestrian accidents will not increase the price of cars and so will not have a deterrent effect on automobile purchases-a factor that also contributes to the accidents.

27. Calabresi, Some Thoughts, supra note 11, at 506.

28. Id.

29. Id. at 506 (emphasis added); see also id. at 545-47.

30. Id. at 506-07. 
(with their associated bargaining power) in some industries. ${ }^{31}$ Calabresi was clearly of the mind, however, that the scope for such arrangements is quite limited, and thus that the traditional economic theory is not likely to apply. In such cases, he said, the assignment of liability is not a matter of indifference, and efficiency considerations dictate that the cost burden be imposed on the party who is "in a better position to allocate the cost of the particular loss to the appropriate activity or merchandise.,"32

Calabresi, then, appears to have laid out his own Coase theorem-type result - in a world without frictions the assignment of liability will give rise to an efficient and invariant allocation of resources-at roughly the same time that Coase was making his point in The Problem of Social Cost. Calabresi's presentation of this result-as one that was well-established in the economics literature-makes for a stark contrast to the incredulity and resistance with which Coase's analysis was met in many quarters, including among economists. ${ }^{33}$ But Calabresi also seemed to be giving rather little practical scope to this result, limiting it to relationships between independent contractors and situations of products liability - a far more narrow set of contexts than Coase himself was contemplating when laying out his own analysis and certainly only a shadow of what was to come in terms of the application of Coase's insights at the hands of others. Why was Calabresi's treatment such a narrow one? And if this result was well established in economic analysis, wherein lies the originality of Coase's 1960 insight? The answers can be found in the distinction between the situations treated by the economists upon whom Calabresi relied and the contexts within which Coase situated his own analysis - a distinction Calabresi brought out forcefully by 1965 .

\section{III}

\section{WORLDS APART}

It was in The Decision for Accidents: An Approach to Nonfault Allocation of Costs (The Decision for Accidents) ${ }^{34}$ that Calabresi first brought Coase's analysis into his own discussion and, at the same time, clarified what had been only implicit in his earlier discussion of market solutions. In The Decision for Accidents, Calabresi emphasized that what allows markets, at least in theory, to deal satisfactorily with harmful effects in certain contexts is the presence of a preexisting or ongoing contractual relationship that can be modified to account for the harmful effect or the potential for harmful effects. ${ }^{35}$ Basic supply-anddemand forces will work to internalize the relevant costs and the market

31. Id. at $506 \mathrm{n} .25$.

32. Id. at 506-07.

33. See, e.g., Stanislaw Wellisz, On External Diseconomies and the Government-Assisted Invisible Hand, 31 ECONOMICA 345 (1964).

34. 78 HARV. L. REV. 713 (1965) [hereinafter Calabresi, The Decision for Accidents].

35. Calabresi illustrated this with reference to Vincent v. Lake Erie Transp. Co., 124 N.W. 221 (Minn. 1910). See Calabresi, The Decision for Accidents, supra note 34, at 726. 
process will, in theory, generate an efficient and invariant result. But again, this was an insight that, as Calabresi emphasized, had long been recognized in the economics literature.

\section{A. Bringing Coase into the Story}

All of this, of course, had very little to do with the context to which Calabresi was addressing a significant part of his analysis: automobile accidents. These accidents, after all, tend to involve interactions-for example, between drivers or between drivers and pedestrians-in which there is no preexisting bargaining relationship. Calabresi ascribed to Coase the insight that the same efficiency and invariance results we observe in "bargaining situations" (Calabresi's term for interactions involving preexisting bargaining relationships) can emerge from the much wider class of cases in which no preexisting market or contractual relationship obtains. ${ }^{36}$ Calabresi's interpretation of Coase's insight was as follows:

\section{The argument runs that if the cost of a factory-smoke nuisance, for instance, is put on the homeowner rather than on the factory, and the cheapest way to avoid this cost is not for the homeowner to move or wear a gasmask but is for the factory to install a smoke-clearing device or cut down production, the homeowner will pay the factory to do this. On the other hand, if the cost is originally put on the factory, and the best way to minimize the loss is to get the homeowners to move, the factory will find it cheaper to pay for such a move rather than to cut down production. Either way, it is argued, the market will find the cheapest way to deter or minimize the loss. And while there may be some difference in the end as to who is richer and who is poorer, in terms of general cost deterrence the same results will be achieved whoever bears the initial loss.}

What Coase had shown, Calabresi reasoned, was that "a bargaining relationship can always be established" between the party on whom the loss originally falls and the party who is best positioned to minimize the loss, and that "[i]n a perfect world such a bargaining relationship will always result in the appropriate minimization of the loss," just as in the case of the preexisting bargaining relationship. ${ }^{38}$

That said, Calabresi found the possibilities associated with actually applying Coase's analysis to the context of accidents very remote, and he did not attempt to offer an illustration of a situation in which Coase's analysis might be put to use, even in theory. Instead, he turned immediately to an elaboration of the problems associated with making use of Coase's result, pointing to the cost of establishing a bargaining relationship, or setting up a market, in the first placeof getting people to the table, so to speak-and free-riding behavior as particularly problematic issues. ${ }^{39}$ Although the presence of a preexisting

36. Calabresi, The Decision for Accidents, supra note 34, at 729 n.26.

37. Id. at 729 .

38. Id. at 730 (emphasis added). See also Guido Calabresi, Changes for Automobile Claims? Views and Overviews, 1967 U. ILL. L.F. 601, 607 [hereinafter Calabresi, Changes for Automobile Claims?] ("Coase's analysis points out that, in theory, any 'independent' situation can be transformed into a bargaining situation.").

39. Calabresi, The Decision for Accidents, supra note 34, at 730-31. 
bargaining relationship offered some hope that efficient deterrence could be accomplished regardless of how liability was assigned, Calabresi was of the mind that absent such a relationship "practical limitations" attending bargains "are significant enough to exclude their being the answer." Calabresi concluded, as he had in The Decision for Accidents, that "[f]or both theoretical and practical reasons... there are many situations in which we cannot assume that it makes no difference, in terms of accident deterrence, who is saddled with the original liability, ${ }^{, 41}$ we are left to assume that the window Calabresi left open referred to the preexisting-bargaining situation and that, from where he stood, Coase's analysis had added little, if anything, to the discussion of practical accident remedies. ${ }^{42}$

\section{B. Reluctant Non-Coasean}

But there is more to Calabresi's commentary on Coase than this applicability-related dismissal would appear to indicate. It seems clear that at the time he wrote The Decision for Accidents Calabresi very much wished he could put Coase's result to actual use. He described Coase's analysis as an "ingenious attempt" ${ }^{43}$ to show that parties not in a preexisting bargaining relationship will arrive at the same position as parties who are in such a relationship and lamented that it was "too bad" that Coase's theory was not "frequently workable." ${ }^{44}$ Why, then, was Calabresi so taken with Coase's result?

One might infer that the answer lies in the resonance between the Coase theorem and Calabresi's goal of achieving an efficient tort-law system. The Coase theorem, after all, tells us that such a result is guaranteed if the world matches up to the relevant assumptions. ${ }^{45}$ But this would be at best an oversimplification and perhaps even completely off the mark. Calabresi's wistfulness for a Coase-theorem world was not, per se, motivated by the alluring implication that, in such a world, we could be indifferent about assignments of liability. Indeed, Calabresi was never, even in theory, indifferent about assignments of liability. Instead, his thinking was more instrumentally oriented: The ability of parties to internalize costs in the absence of a

40. Guido Calabresi, Fault, Accidents and the Wonderful World of Blum and Kalven, 75 YALE L.J. 216, 231-32 n.28 (1965) [hereinafter Calabresi, Wonderful World]. Calabresi was reacting against Blum and Kalven, who also had taken up Coase's negotiation result, only to immediately dismiss it on the grounds of irrelevance. See Walter J. Blum \& Harry Kalven, Jr., Public Law Perspectives on a Private Law Problem-Auto Compensation Plans, 31 U. CHI. L. REV. 641 (1964) [hereinafter Blum \& Kalven, Public Law Perspectives].

41. Calabresi, The Decision for Accidents, supra note 34, at 731.

42. The "theoretical" reason goes to a critique that Calabresi leveled against Coase's result, which is discussed in part IV.

43. Calabresi, Wonderful World, supra note 40, at 231.

44. Id. at 231-32 n.28. That the dispute between Blum and Kalven on the one hand and Calabresi on the other did not go to the validity of Coase's negotiation result is reflected in Blum and Kalven's 1967 rebuttal to Calabresi. See Walter J. Blum \& Harry Kalven, Jr., The Empty Cabinet of Dr. Calabresi: Auto Accidents and General Deterrence, 34 U. CHI. L. REV. 239, 264 n.53 (1967).

45. See supra pp. 66-67. 
preexisting bargaining relationship would make his preferred guidelines for assigning liability in the bargaining case just that much more broadly applicable. ${ }^{46}$ To understand Calabresi's logic here, we need to return to the case of the preexisting bargaining relationship.

Calabresi was of the mind that, in theory, the assignment of liability would not affect allocation if the parties were in a preexisting bargaining relationship. But reality, he said, can be far-removed from economic theory. ${ }^{47}$ Given this, Calabresi noted, we cannot depend on market processes to generate an efficient and invariant outcome and instead need to focus attention on several factors that determine, from a deterrence perspective, which party is the better loss bearer. These factors, he said, include:

1) which of the parties can better evaluate the risk involved; 2) which of the parties can better evaluate the accident proneness of potential parties on the other side; 3 ) which of the parties can better let this knowledge, when significant, be reflected in the prices it can command; 4) which of the parties can more cheaply insure against the liability; and 5) placing liability on which of the two parties is less likely to cause the loss to be removed from both, for compensation or other reasons. ${ }^{48}$

That is, as the bargaining theory tells us, we can expect that costs will be internalized into the price, but we can only be assured that they will be properly or efficiently internalized if rights are assigned appropriately in light of the guidance provided by the factors enumerated above. ${ }^{49}$ If rights are not assigned appropriately, higher than optimal costs will be translated into market prices, and the end result will be inefficient. ${ }^{50}$

This allows us to understand why Calabresi expressed regret over what he considered the largely irrelevant nature of Coase's result. It was not that the cost-minimizing outcome would obtain regardless of how rights are assigned. Instead, his view was that, "were Coase's theory frequently workable," the above-enumerated "guidelines for liability derived in the bargaining case would apply [in the absence of a preexisting bargaining relationship] as well." ${ }^{, 51}$ In Calabresi's world, getting to efficiency is a multistep process. The first step is to assign liability to those parties-or, more accurately, to that class of agents (drivers, pedestrians, and so forth) - who can most cheaply internalize the relevant costs. ${ }^{52}$ The second step is to translate these costs into the prices faced by all agents. ${ }^{53}$ On Calabresi's reading, what Coase had provided was the key to unlocking this second step in the absence of an existing bargaining or market relationship: That is, the establishment of liability allows for the creation of a market framework for interaction that was not previously present. But if the

46. See Calabresi, Wonderful World, supra note 40.

47. Id. at 230 .

48. Id. at $230-31$.

49. Id. at 224,231 .

50. Id. at 224 .

51. Id. at 231-32 n.28.

52. Id. at 225 .

53. Id. 
costs of establishing such a market are too high, as Calabresi expected they generally would be, there is no mechanism for transmitting the relevant costs into each of the prices faced by each of the affected parties. ${ }^{54}$ The costs, therefore, are not internalized in a way that will generate efficient outcomes. If one could be assured that the establishment of liability would lead to the creation of a bargaining relationship, then the translation of costs into price would be assured, and the only efficiency-related task would be ensuring that liability is assigned to the party who could internalize the harm at lowest cost. The above-enumerated factors would provide guidance in achieving this goal, just as in the case of a preexisting bargaining relationship. ${ }^{55}$ But alas, Calabresi considered this prospect extremely remote. ${ }^{56}$

\section{Ronald's World Versus Guido's World}

Though it is commonly suggested in the Coase-theorem literature and appears, on the face of it, that Coase and Calabresi were speaking the same language, the preceding paragraphs suggest that this is not case. Yes, like Voltaire's Dr. Pangloss, both of them were of the mind that all is for the best in the best of all possible worlds, ${ }^{57}$ and their respective discussions were tempered by the recognition - amply evident in both Coase's discussion and Calabresi'sthat transaction costs tend to get in the way in the real world. ${ }^{58}$ In fact, however, the worlds about which they spoke-that is, the contexts within which they laid out their respective analyses-were rather different, and hints of these differences are evident both in Calabresi's earliest discussions of Coase's insight and throughout his subsequent writings on this subject.

One of the things that stands out when studying Calabresi's discussion of tort remedies, including Coasean solutions, is that these analyses are consistently conducted on a large-numbers or market level. Calabresi's Coase theorem was not one that involved, or at least focused on, the two-party, bilateral exchange analysis of Coase's farmer and cattle rancher $^{59}$ or of the physician and the confectioner in Sturges $v$. Bridgman. ${ }^{60}$ Instead, the parties involved are the class of injurers and the class of victims, as in his discussions of automobile manufacturers, drivers and pedestrians, farmers and cattle ranchers, and the like. ${ }^{61}$ Calabresi was speaking of the possibilities and problematics of accident-costs internalization within a market process involving these classes of

54. Calabresi, The Decision for Accidents, supra note 34, at 730-32.

55. Calabresi, Wonderful World, supra note 40, at 224, 231; Calabresi, The Decision for Accidents, supra note 34 , at 730 .

56. Calabresi, Wonderful World, supra note 40.

57. Voltaire, CANDide, OR, OPTIMISM 4 (Theo Cuffe ed. \& trans., Penguin Books 2005) (1759).

58. See Coase, The Problem of Social Cost, supra note 1, at 15. On Calabresi, see infra pp. 75-76.

59. See infra pp. 75-76.

60. See Sturges v. Bridgman, (1879) 11 Ch.D. 852 (U.K.) (involving a physician whose ability to practice medicine was impeded by the noise emanating from the premises of an adjacent confectioner).

61. See, e.g., CAlabresi, Costs, supra note 15, at 136; Calabresi, The Decision for Accidents, supra note 34 , at 730 n.28. 
agents, and his quest was for legal rules that would internalize costs to the relevant class(es) of actors in a way that minimized accident-related costs. Coase, in contrast, devoted his attention to two-party situations, where there is a single injurer and a single victim. ${ }^{62}$

This, then, brings us to the crux of Calabresi's interest in Coase's negotiation result and, indeed, to his conceptualization of Coase's insight in The Problem of Social Cost. The Coase theorem, for Calabresi, said, in effect, that where a market does not exist to internalize costs, the assignment of liability will have the effect of creating a set of market or market-like interconnections between classes of agents that will cause relevant costs to be reflected in the prices faced by all agents - in the case of automobiles, for example, all drivers and all pedestrians. ${ }^{63}$ And in a world without frictions, the market processes envisioned by Calabresi and the negotiation processes contemplated by Coase will, by their respective logics, generate efficient and invariant outcomes. ${ }^{64}$

This large numbers-small numbers distinction has important implications for our understanding of what Calabresi was on about in his discussions of the Coase theorem. The most significant of these implications arises in his discussion of transaction costs, which, for Calabresi, meant "costs like those of getting large numbers of people together to bargain, and costs of excluding free loaders. " ${ }^{65}$ The focus here is on the cost of setting up a market-a recurrent theme in Calabresi's commentaries on the Coase theorem. ${ }^{66}$ Coase, in contrast, placed significant emphasis on the costs associated with the negotiation process itself - costs to which Calabresi, for his part, paid little attention. ${ }^{67}$ In fact, it was only in The Costs of Accidents, in 1970, that Calabresi modified his discussion to include an emphasis on the costs associated with the negotiation context itself. ${ }^{68}$

62. In fact, Calabresi did Coase one better by arguing that liability in the conflict between polluters and those who suffer from pollution could be assigned to some third-party class of agents (for example, television manufacturers) and these agents then would undertake the bribes necessary to bring about the efficient result if transaction costs were zero. See Calabresi, The Decision for Accidents, supra note 34 , at $731-32$ n.30.

63. See id. at 729-30.

64. It should be noted that this result holds regardless of the number of parties in Coase's negotiation scheme. That is, if transaction costs are zero, the number of negotiating parties is irrelevant. When it comes to actually applying the result in the real world, however, the assumption of zero transaction costs becomes increasingly tenuous as the number of parties to the bargain increases, as Coase recognized.

65. Guido Calabresi, Transaction Costs, Resource Allocation and Liability Rules-A Comment, 11 J.L. \& ECON. 67, 68 n.5 (1968) [hereinafter Calabresi, Transaction Costs].

66. The earliest mentions of this occur in Calabresi, The Decision for Accidents, supra note 34, at 730-31, and Calabresi, Wonderful World, supra note 40, and we find this theme carried through his discussions of Coase's result in the 1970s, see infra Part VI.

67. See Coase, The Problem of Social Cost, supra note 1, at 15. Calabresi was well aware of the fact that his conception of transaction costs differed significantly from that of Coase, though he never made a connection between their respective emphases and the distinction between the large-numbers character of his own analysis and the small-numbers character of Coase's. See Calabresi, Transaction Costs, supra note 65.

68. CALABRESI, COSTS, supra note 15. 
The costs of establishing a market and the problem of free riding, of course, are not relevant in the case of the preexisting bargaining relationship, because a market through which costs could potentially be internalized is already in place. In the absence of a preexisting bargaining relationship, however, a market within which all potential injurers and potential victims interact must be established for costs to be internalized, and this process, as Calabresi recognized, is almost certain to be extremely (and likely prohibitively) costly. ${ }^{69}$ Moreover, a handful of free-riding agents can destroy the entire process. ${ }^{70}$ In Coase's two-party bargaining situations, by contrast, these considerations are not terribly relevant: There is no market to be set up, because one party needs only to commence the process of negotiating with the other, and there are no parties on whose actions one can free ride. Although Coasean bilateralnegotiation processes are by no means costless in the real world, this environment would seem to offer a context better suited to negotiated solutions than would the background against which Calabresi articulated his analysis of tort remedies.

\section{IV}

\section{FINDING A FLY IN THE OINTMENT}

Though Calabresi found Coase's insight both interesting and important, if rather unrealistic, he was skeptical that all was right with it, even from the start. In The Decision for Accidents, Calabresi again drew upon his economics training, this time to point out what he believed was a flaw in Coase's conclusion. $^{71}$

The problem, for Calabresi, lay not in Coase's analysis per se, but in whether his result would hold true in the long run as well as in the short run. ${ }^{72}$ Calabresi's specific point of concern was that different flows of liability-related costs attending alternative assignments of liability would affect incentives for entry into and exit from the affected industries and thus generate different longrun levels of output, or of harm-causing activity, or both. To make his point, Calabresi invoked Coase's farmer-rancher illustration. In doing so, he situated both farmers and ranchers in "a perfectly competitive world" and assumed an initial situation in which ranchers are liable for the harm done by their cattle. ${ }^{73}$ Calabresi noted that once the parties have negotiated their way to an efficient resolution of the problem, à la Coase, economic theory informs us that "just enough cattle raisers and enough farmers will engage in each business at this

69. See id. at $136-38$.

70. See id. at 137 n.4.

71. To that point, there had been only one critique-by Columbia University economist Stanislaw Wellisz-leveled against the theoretical correctness of Coase's negotiation analysis. See Wellisz, supra note 33, at 350-54 (arguing that Coase's result requires that at least one agent be earning rents and that the bargaining process might create incentives for inefficiency-generating blackmail activities).

72. Calabresi, The Decision for Accidents, supra note 34, at 730 n.28.

73. Id. 
equilibrium so that the marginal farmer and the marginal cattle raiser will each earn the same return on his investment-the same return in fact available in any other nonmonopolistic activity." ${ }^{, 7}$ In short, the parties would arrive at an efficient equilibrium outcome. So far, so good.

But suppose, he said, that we alter the assignment of liability. Coase's analysis tells us that the result should be unchanged, but Calabresi felt that a careful economic analysis of the situation would not sustain such a claim. The farmers, of course, are now forced to bear the costs associated with the harm and, as a result, will earn a correspondingly lower rate of return. Ranchers, meanwhile, having been absolved of liability, will receive a correspondingly higher rate of return. This, Calabresi asserted, was where Coase's conclusion unraveled: "Assuming, as Coase must in his perfect world, free entry and exit, people will move into cattle raising from neutral occupations, and people will leave farming to enter these same neutral occupations." ${ }^{75}$ As a result, said Calabresi, the new equilibrium that is established will include more ranchers and fewer farmers, and thus more cattle and fewer crops, than did the original equilibrium. $^{76}$ Thus, invariance does not obtain in the long run. Rather, these long-run entry and exit effects generate asymmetric levels of output across alternative assignments of liability.

The problems for the theorem, however, did not end there. Calabresi also argued that this long-run entry-exit process gives rise to misallocations-that is, to inefficiencies. ${ }^{78}$ The initial bargaining activity generated an efficient mix of crops and cattle, as Coase had demonstrated, but given this efficiency, he said, the subsequent entry and exit effects associated with allocating the cost of externalities to farmers must give rise to an inefficiently large number of cattle and an inefficiently small amount of crops. ${ }^{79}$ The entry and exit critique thus appeared to invalidate both the theorem's efficiency claim and its invariance claim. What Coase's analysis had really shown, according to Calabresi, is that "the market will operate through artificial bargains to mitigate the effect of the misallocation but not to correct it altogether."

74. Id.

75. Id.

76. Id.

77. Calabresi's critique of the Coase theorem on the grounds of entry and exit effects is an excellent illustration of the large-numbers market-oriented nature of Calabresi's framework, discussed in part III.C, and of the Coase theorem-related implications of adopting this framework. Calabresi's criticism depends on the idea that certain industries impact certain other industries and that the effects are industry wide. In the situations contemplated by Coase, an individual firm was in conflict with another individual firm - a cattle rancher happened to be operating on land adjacent to a farmer, a physician happened to have his examination rooms located immediately adjacent to the noisy operations of a confectioner, and so on-meaning that, in the scenarios contemplated by Coase, the industry-wide impacts, and thus, the entry and exit effects pointed to by Calabresi, are not relevant.

78. Calabresi, The Decision for Accidents, supra note 34, at 730 n.28.

79. Id.

80. Id. at $731 \mathrm{n} .30$ (emphasis added). Calabresi was not certain, though, that Coase would support a bargaining outcome of this nature. As Calabresi noted, "Mitigation is good enough for me and the analysis in this article; whether it suits Professor Coase as well, I do not know." Id. at 730 n.28. 
It would seem, then, that Calabresi had introduced a fly into the Coasean ointment, one of far greater potential significance than the practical concerns that he had raised about implementation in the accident realm. ${ }^{81}$ Even so, Calabresi was not convinced of the correctness of his own critique, which he introduced only in a footnote and began with a disclaimer stating, "It is not clear to me" that Coase's result will hold up in the long run. ${ }^{82}$ One page later, Calabresi chose to refer to his "doubts about" whether Coase's result holds up over time ${ }^{83}$ rather than to refer back to a result that he had in some sense "demonstrated." In short, Calabresi did not claim to have disproved Coase's result, but to have called it into question. The reason for Calabresi's qualms about the correctness of his own analysis are unclear, though one might speculate that, given the somewhat limited extent of his economics training, he was uncomfortable making a definitive claim against an economist on a point of economic theory-particularly because the point being made by Calabresi involved rather elementary price theory that one would not expect a professor of economics to have overlooked. Nonetheless, the combined weight of this theoretical concern and the practical problems posed by the presence of transaction costs led Calabresi to conclude that "we cannot assume that it makes no difference ... who is saddled with the original liability," even in the frictionless world contemplated by Coase. ${ }^{84}$

\section{$\mathrm{V}$ \\ REMOVING THE FLY, AND FINDING NIRVANA}

One might argue that Calabresi's qualms about his critique of Coase's result were, in retrospect, justified. For despite his not inconsiderable economics background, Calabresi soon concluded that he did not quite get it right in his 1965 challenge to Coase's analysis, as he admitted in a brief article on this subject, Transaction Costs, Resource Allocation, and Liability Rules-A Comment, published in the Journal of Law and Economics in $1968 .^{85}$

On what basis did Calabresi retract his earlier criticism? In essence, he invoked the Coase theorem in defense of the Coase theorem and, in doing so, began to peel back the layers to expose the properties of life in a Coasetheorem world. Calabresi's argument was very straightforward: Given the existence of long-run misallocations caused by entry and exit effects, "the same type of transactions which cured the short run misallocation would also occur to cure the long run ones. ${ }^{\not 66}$ For example, if, after entry and exit effects, farming

81. See supra Part III.

82. Calabresi, The Decision for Accidents, supra note 34 , at 730 n.28.

83. Id. at 731 n.30.

84. Id. at 731 .

85. See Calabresi, Transaction Costs, supra note 65, at 67. By this time, the Journal of Law and Economics was being edited by Coase, and Calabresi thanked both Coase and Yale Law School colleague Ward Bowman, himself a Chicago product of sorts, for discussions related to various aspects of this note. See id. at $67 \mathrm{n} . *$.

86. Id. at 67 . 
output is too low relative to manufacturing output, said Calabresi, "those who lose from this 'misallocation' would have every reason to bribe farmers to produce more and factories to produce less," a process that, according to Calabresi, would continue until the misallocation had been fully corrected. ${ }^{87}$ Efficiency and invariance, then, would obtain in both the short run and the long run after all.

Calabresi, however, was not content to stop at this mea culpa. Instead, he pushed the Coasean envelope even further by claiming that, at least in theory, the domain of Coase's negotiation result goes well beyond the joint cost-user contexts that were the focus of Coase's-and his own previous-analysis (that is, beyond situations involving what economists typically label "externalities"). ${ }^{88}$ Properly understood, Calabresi argued, Coase's analysis showed that "if one assumes rationality, ${ }^{89}$ no transaction costs, and no legal impediments to bargaining, all misallocations of resources would be fully cured in the market by bargains. ${ }^{\prime 00}$ That is, in a Coase-theorem world, there will be no inefficiencies whatsoever; ostensible market failures will always be efficiently resolved via bargaining between affected parties, whatever their number and the context of the problem. ${ }^{91}$ In Calabresi's hands, then, the Coase theorem was a far more powerful tool than Coase himself had suggested.

Calabresi had thus moved very quickly from skeptic to true believer and, having recanted his earlier charge against the Coase theorem, proceeded to offer his most penetrating insight into the theorem to that point, an insight that could be considered either laudatory or damning, depending on one's perspective:

Far from being surprising, this statement is tautological, at least if one accepts any of the various classic definitions of misallocation. These ultimately come down to a statement akin to the following: A misallocation exists when there is available a possible reallocation in which all those who would lose from the reallocation could be fully compensated by those who would gain, and, at the end of this compensation process, there would still be some who would be better off than before.

87. Id. at 67-68. Economists continued to debate for some time whether there were other, valid reasons why the entry-and-exit critique was legitimate. See, e.g., Medema \& Zerbe, supra note 7 (containing numerous references to this literature).

88. Calabresi, Transaction Costs, supra note 65, at 68.

89. It should be noted that Coase did not assume rationality, nor did he make any other explicit behavioral assumptions in his analysis. What is implicit in Coase's discussion is that agents will pursue opportunities for gain. See, e.g., Coase, The Problem of Social Cost, supra note 1, at 15.

90. Calabresi, Transaction Costs, supra note 65, at 68 (emphasis added). It might appear from this statement that Calabresi is offering a Coase theorem that includes only the efficiency proposition and not a claim of invariance. However, Calabresi's accompanying footnote informs us that allocation is not affected. See id. at 68 n.4. See also id. at 69 (discussing legal rules that replicate "the" market result that would obtain under zero transaction costs).

91. University of Chicago economist Harold Demsetz made a nearly identical claim in an article published in that same year. See Harold Demsetz, The Cost of Transacting, 82 Q.J. ECON. 33, 33 (1968) ("The usual sources of inefficiency fail to exist in such an economic system."). 
However, he continued:

This and other similar definitions of resource misallocation merely mean that there is a misallocation when a situation can be improved by bargains. If people are rational, bargains are costless, and there are no legal impediments to bargains, transactions will ex hypothesis occur to the point where bargains can no longer improve the situation; to the point, in short, of optimal resource allocation. We can, therefore, state as an axiom the proposition that all externalities can be internalized and all misallocations, even those created by legal structures, can be remedied by the market, except to the extent that transactions cost money or the structure itself creates some impediments to bargaining.

Calabresi was the first, but by no means the last, to label the Coase theorem a tautology. ${ }^{93}$ In Calabresi's hands, though, the theorem was a useful tautology, for reasons that became apparent in his subsequent commentaries on Coase's result.

Having finally grasped the nirvana-esque properties of the Coase theorem, Calabresi made something of a transition in his discussion of it over the next two decades. The theorem, in effect, became an instrumental tool used by Calabresi to make a variety of points grounded in the theorem's very utopian nature. One of these points involved making the theorem a centerpiece, or benchmark, in his discussions of tort law-a trend that began with his analysis in The Costs of Accidents. ${ }^{94}$ Though much of The Costs of Accidents was already penned in 1965, the year in which Calabresi's critique of the Coase theorem was published, the influence of his 1968 about-face on the book is clear. Indeed, The Costs of Accidents provides perhaps the best illustration of Calabresi's newfound sense for the importance of the Coase theorem: Coase's result became the basis for the book's analysis of market-oriented solutions to tort law problems. Duncan Kennedy has recently commented that The Costs of Accidents "was much better than the articles that [Calabresi had] written up till then." ${ }^{95}$ As justification for this comment, Kennedy noted that "[t]he articles were all basically somewhat confused in their encounter with the Coase theorem. ${ }^{, 96}$ From where Kennedy stood, it was only in The Costs of Accidents that Calabresi developed "a coherent way of understanding the Coase theorem as a lawyer." 97

Calabresi's discussions of accident law prior to The Costs of Accidents had led with the preexisting-bargaining case and paid much less attention to Coase's negotiation result—relegating much of the discussion to footnotes. ${ }^{98}$ In The

92. Calabresi, Transaction Costs, supra note 65, at 68 .

93. See, e.g., Michael C. Jensen, Foundations of Organizational Strategy 141 (1998); Warren J. Samuels, The Coase Theorem and the Study of Law and Economics, 14 NAT. RESOURCES J. 1, 4, 31 (1974); Cento G. Veljanovski, The Coase Theorem: The Says Law of Welfare Economics? 53 ECON. REC. 535 (1977).

94. CALABRESI, COSTS, supra note 15.

95. JAMES R. HACKNEY, LEGAL INTELLECTUALS IN CONVERSATION: REFLECTIONS ON THE CONSTRUCTION OF AMERICAN LEGAL THEORY 21 (2012).

96. Id.

97. $I d$.

98. See, e.g., Calabresi, The Decision for Accidents, supra note 34, at 730-31; Calabresi, Wonderful 
Costs of Accidents, however, Calabresi opened his analysis of market solutions with a lengthy treatment of Coase's result, its implications, the problematic nature of real-world negotiated solutions, and how best to proceed in light of these problems, only taking up the preexisting-bargaining case at the end of the chapter in a discussion that he labeled "[a] Detour." essentially painting the preexisting-bargaining case as a special case of the Coase theorem rather than, as he had done in the past, portraying the Coase theorem as a complement to the bargaining case. More significant, however, was his contention that "distinguishing this area"-the bargaining case-from cases such as those contemplated by Coase "only serves to confuse matters in practice." 100 Thus, having taken pains in his previous writings to separate this case and the independent-agents context contemplated by Coase, Calabresi now lumped them together. Why Calabresi made this alteration to his discussion is unclear, but a reasonable surmise is that it grew out of the broad domain that he assigned to the Coase theorem in his 1968 article. ${ }^{101}$ This may also explain why Kennedy considers The Costs of Accidents to have provided a more coherent treatment of the Coase theorem than did Calabresi's earlier writings. ${ }^{102}$ All of this said, Calabresi was by no means the first to lump together the bargaining and independent cases. His distinction had disappeared in commentaries on his and Coase's analyses made by other legal scholars throughout the second half of the 1960s, and these commentators had been only too eager to ascribe both the bargaining-case insight and the independentagents insight to Coase-in apparent ignorance of the former's lengthy legacy in economic analysis. ${ }^{103}$

But this benchmark aspect of the Coase theorem played a further and perhaps more important role in Calabresi's writing, one that involved using the Coase theorem as something of a guide to and perhaps even justification for real-world judicial decision making. As Calabresi pointed out in 1968, the effect of Coase theorem-type bargains is to minimize the costs of accidents. ${ }^{104}$ Thus, if efficiency is the goal for law, this implies that " $[\mathrm{t}]$ he resource allocation aim is to approximate, both closely and cheaply, the result the market would bring about if bargaining actually were costless." ${ }^{105}$ Calabresi thought this point sufficiently important to lead with it in his discussion of general deterrence in chapter seven of The Costs of Accidents, arguing that minimizing accident costs

is the same as saying that the system would allocate the costs to those acts or activities that an arbitrary initial bearer of accident costs would (in the absence of transaction

World, supra note 40, at 231-32.

99. CALABRESI, COSTS, supra note 15, at 161.

100. Id. at 162 .

101. See Calabresi, Transaction Costs, supra note 65, at 68.

102. HACKNEY, supra note 95, at 21.

103. See Medema, Debating Law's Irrelevance, supra note 5 (discussing the early treatments of Coase's negotiation result in the legal literature).

104. Calabresi, Transaction Costs, supra note 65, at 71-72.

105. Id. at 69 . 
and information costs) find it most worthwhile to "bribe" in order to obtain that modification of behavior which would lessen accident costs most. ${ }^{10}$

Calabresi overtly grounded this insight in Coase's negotiation result. ${ }^{107}$ In doing so, Calabresi brought the "mimic the market" criterion into legal thinking well before Richard Posner made it famous, ${ }^{108}$ and Calabresi used the Coase theorem to provide the theoretical justification for this approach. ${ }^{109}$

For Calabresi, then, the "transactions costs-free fairyland" of the Coase theorem, as economist Alan Randall later described it, ${ }^{110}$ offered an organizing principle for thinking about market and market-like solutions to legal issues, provided a guide to and justification for thinking about efficiency-based judicial decision making, and promised a tool for assessing the conditions necessary for legal rules to generate an efficient allocation of resources. A tautology, yes, but one that was, in Calabresi's hands, both interesting and useful.

\section{VI}

\section{COASEAN SOLUTIONS IN THE REAL WORLD}

Though Calabresi's 1968 defense of the Coase theorem, like his previous discussions of Coase's result, made no bones about the existence-and perhaps problematic nature - of transaction costs, he did not minimize the potential import of efficiency-enhancing negotiated solutions in situations of the sort that he believed had been unlocked by Coase's discussion. Although this may appear curious in light of the mythical, nirvana-esque properties that Calabresi associated with a Coasean world and the efforts to which he went in laying out problems with attaining the efficient and invariant negotiated solutions contemplated by the Coase theorem, we can achieve some measure of clarity on this score by understanding a distinction that Calabresi made in his writings between the Coase theorem and a broader point that he saw emerging from Coase's analysis in The Problem of Social Cost.

Calabresi's 1968 discussion, although not employing the term "Coase theorem," is emblematic of the theorem as Calabresi conceived it. It is noteworthy that Calabresi used the term only a handful of times in his numerous commentaries on Coase's negotiation result-the first coming in Property Rules, Liability Rules, and Inalienability: One View of the Cathedral

106. CALABRESI, COSTS, supra note 15 , at 135.

107. See id. (noting that, absent transaction costs, "[t]his formulation implies" that it would not matter "who bore the accident costs initially," because "there would be bribes or transactions bringing about any change ... that would cause a greater reduction in accident costs than in pleasure").

108. See Richard A. POSNER, ECONOMIC ANALYSIS OF LAW 17-18 (1973).

109. Calabresi also at times used the Coase theorem to combat what he considered erroneous or hopelessly unrealistic positions adopted by others, as in his 1971 assault on Richard Posner's defense of the efficiency of the Learned Hand formula, see Guido Calabresi \& Jon T. Hirschoff, Toward a Test for Strict Liability in Torts, 81 YALE L.J. 1055, 1058 (1972), and his 1975 critique of the fault system, Guido Calabresi, Optimal Deterrence and Accidents, 84 YALE L.J. 656, 657 (1975) [hereinafter Calabresi, Optimal Deterrence].

110. Alan Randall, Property Rights and Social Microeconomics, 15 NAT. RESOURCES J. 729, 741 n.44 (1975). 
(One View of the Cathedral), his 1972 article with Douglas Melamed ${ }^{111}$-and, in fact, there were only two occasions on which he actually specified what he meant by the term. The first was in Tragic Choices, coauthored with Philip Bobbitt, where Calabresi said, "Coase's theorem ... advises us that (assuming no transaction costs) the market will achieve Pareto optimality regardless of initial entitlements or liability rules." 112 A few years later, in a 1983 commentary on some remarks by Richard Epstein on the subject of products liability, Calabresi offered a more expansive, but essentially equivalent statement of the theorem: "The 'Coase Theorem' states that, assuming the absence of transaction costs, imposing liability on a particular party will not affect the efficiency of the party's undertaking; the incentives created by a liability burden will always be shifted through bargaining onto the party best able to act on them." 113 Both of these statements appear to be what one might call gardenvariety versions of the Coase theorem, though they are not completely consistent with Calabresi's 1968 commentary on this subject in the Journal of Law and Economics in that these later statements do not explicitly include the invariance proposition. ${ }^{114}$ Even so, when Calabresi illustrated the theorem's efficiency-generating magic by applying Coase's insight to tort situations involving large classes of potential injurers and victims, Calabresi's illustrations had that too-good-to-be-true utopian quality one would expect from application to those situations in which large numbers of agents must negotiate their way to solutions acceptable to each of them. ${ }^{115}$ But those illustrations, as Calabresi emphasized, were not the "real world."

When it came to the real world, Calabresi was not willing to completely jettison Coase's analysis. Instead, he repeatedly referred to a rather more benign version of Coase's result, the idea that parties will negotiate to efficiency-enhancing positions when it makes sense to do so-that is, when it is cost effective. ${ }^{117}$ This, of course, brings us back to the issue of transaction costs. Although Calabresi's earliest discussions of the Coase theorem emphasized "the cost of establishing [bargaining] relationships" as the chief hurdle to be overcome ${ }^{118}$ he did not believe that these costs inevitably constituted an insuperable barrier to market-based solutions to ostensible problems of market failure. As he and Bobbitt argued in Tragic Choices, "Professor Ronald Coase has pointed out [that] markets could cure all such defects"-problems

111. See 85 HARV. L. REV. 1089, 1118 n.59 (1972). Calabresi and Melamed did not give the term a specific definition.

112. Guido CAlabresi \& Philip Bobbitt, Tragic ChOices 85 (1978).

113. Guido Calabresi, Commentary, 58 N.Y.U. L. REV. 939, 943 n.12 (1983).

114. See supra note 90 and accompanying text.

115. See, e.g., CAlABresi, Costs, supra note 15, at 136; Guido Calabresi, First Party, Third Party, and Product Liability Systems: Can Economic Analysis of Law Tell Us Anything About Them? 69 IOWA L. REV. 833, 839-40 (1984) [hereinafter Calabresi, First Party, Third Party, and Product Liability Systems].

116. Calabresi, First Party, Third Party, and Product Liability Systems, supra note 115, at 839.

117. See, e.g., Calabresi, Optimal Deterrence, supra note 109, at 659.

118. Calabresi, Wonderful World, supra note 40. 
associated with monopoly, public goods, and externalities- "if the cost of setting up the curative market were low enough." 119 Once established, Calabresi seemed to have some confidence that the market would do a reasonable job of appropriately allocating costs and transmitting them into prices-a confidence borne of his view that the efficacy of the market was a "probably justifiable empirical conclusion." ${ }^{120}$

Calabresi offered various scenarios in which such bargaining solutions might manifest themselves, some that involved fairly low transaction costs and others that even countenanced the possibility that these costs are significant. The lowtransaction-cost contexts mentioned by Calabresi tended to involve situations in which a bargaining relationship is already present and, as such, represented both a continuation of his early emphasis on the possibility of market solutions in the preexisting-bargaining case and his post-1970 tendency to lump these cases into the Coase-theorem framework. ${ }^{121}$ When discussing liability rules in One View of the Cathedral, for example, Calabresi and Melamed pointed out that although many accident-related negotiations are likely to be extremely (and often prohibitively) expensive, there are times when "preaccident negotiations between potential injurers and victims are ... not too costly," such as in "a typical products liability situation" where the seller may offer the product at a reduced price if the buyer agrees not to sue in the event that he is injured. ${ }^{122}$

Calabresi actually provided a specific illustration of such a Coasean process at work in his 1984 comparison of various liability systems for automobile accidents. ${ }^{123}$ After pointing out that each of these liability systems generates an efficient result in "the Coasian world of no transaction costs," 124 he continued by noting that some transactions of the Coasean variety do occur "even in our far from frictionless world," practice of offering a thirty-percent discount on the medical portion of automobile insurance for drivers whose cars have air bags-an insight he garnered from a telephone conversation with a corporate-relations representative at Allstate. ${ }^{126}$ Such was Calabresi's confidence in the propensity of markets to facilitate this type of result that he went the further step of

119. CALABRESI \& BoBBITT, supra note 112, at 83 (emphasis added).

120. Calabresi, Transaction Costs, supra note 65, at 68 n.5. That said, Calabresi was not completely confident that his conclusions were valid under Coase's conception of transaction costs-those pertaining to the costs of negotiation per se: "With the kinds of costs which Coase seems to call transaction costs, that conclusion, though possibly often still valid, cannot be accepted without more data." Id.

121. See supra Part III.

122. Calabresi \& Melamed, supra note 111, at 1109 n.38 (emphasis added). Calabresi argued a similar point in a 1985 article assessing different tests for tort liability. See Guido Calabresi \& Alvin Klevorick, Four Tests for Liability in Torts, 14 J. LEgAL STUD. 585, 609-10 (1985).

123. See Calabresi, First Party, Third Party, and Product Liability Systems, supra note 115.

124. Id. at 839 .

125. Id. at 840 .

126. Id. at 840 n.26. 
asserting that we might well see even more transactions of this sort "if we did not-for good reasons, like those suggested by the antitrust laws-make some agreements and transactions more difficult than they otherwise would be."127 Once again, it bears keeping in mind that both the products-liability and autoinsurance examples cited by Calabresi involve preexisting bargaining relationships. But putting to one side the correspondence or lack thereof with Coase's insight, the point is that Calabresi was of the mind that private transactions can resolve these inefficiencies even where the costs of transacting are positive.

There was, however, a second class of situations to which Calabresi felt that Coase's negotiation insight was applicable, even, potentially, when transaction costs are quite high. I have already noted Calabresi's concern about the problems associated with identifying the least-cost avoider-an issue that came up quite regularly in his discussions of accident law. ${ }^{128}$ It was here, though, that Calabresi felt Coase's negotiation analysis provided a potential remedy for situations in which judges have guessed wrong and allocated costs to the wrong activity: Coase theorem-like negotiations have the potential to correct errors in the assignment of liability. ${ }^{129}$

Calabresi's take on this had both a positive and a normative aspect. The positive side of this insight made its first appearance in Calabresi's 1965 commentary on Blum and Kalven ${ }^{130}$ and was repeated by Calabresi and Melamed in One View of the Cathedral. ${ }^{131}$ As Calabresi and Melamed put it, "If we were wrong in our judgments and if transactions between [the parties] were costless or even very cheap, the entitlement... would be traded and an economically efficient result would occur in either case." ${ }^{132}$ That is, Calabresi was of the mind that efficient negotiated solutions, à la Coase, can be achieved even when transaction costs are nonzero and the parties are not involved in a preexisting bargaining relationship. Although one might be inclined to wave this aside on account of the low transaction costs assumed by Calabresi and Melamed, the fact is that Calabresi managed to find an element of real-world applicability in Coasean bargaining even when transaction costs are significant, as is evident in his 1965 critique of Blum and Kalven's complete dismissal of Coase's analysis. ${ }^{133}$ In spite of the overall pessimism about the feasibility of negotiated solutions expressed in that article, Calabresi said that, in light of Coase's analysis, "egregious mistakes made in assigning liability in non-

127. Id. at 840 .

128. See, e.g., Calabresi, The Decision for Accidents, supra note 34, at 732.

129. See, e.g., Calabresi, Transaction Costs, supra note 65, at 72 ("Is an erroneous placing of liability on car owners or an erroneous placing of liability on pedestrians more likely to be corrected in the market?").

130. Calabresi, Wonderful World, supra note 40.

131. See Calabresi \& Melamed, supra note 111, at 1118.

132. Id.

133. See Calabresi, Wonderful World, supra note 40 (referring to "the practical limitations" on the bargains contemplated by Coase). 
bargaining situations may, at least in part, be mitigated through Coasian 'deals' between independent parties." ${ }^{\text {"34 }}$ Though not willing to go all the way, or perhaps even very far, with the idea that bargaining can resolve social-cost problems, Calabresi's feeling was that if the inefficiency is sufficiently great, it will be worthwhile for the involved parties to take on the transaction costs in order to improve their situation. ${ }^{135}$

But the possibilities of the market did not end there. Calabresi was also of the mind that this self-correcting process could be aided by assignments of liability informed by Coase's insight, and here he put a normative spin on the issue. If, as will often be the case, we are uncertain about which party is the least-cost avoider, he said, the operative question becomes, Which mistaken allocation can be cured most cheaply by parties entering into transactions with each other in the market? The rule that emerges from this line of thinking, for Calabresi, is that, unless we are quite certain which of the parties is the leastcost avoider, "we should put the burden on the party which can cure a mistake most cheaply if one has been made, and thus help the market to operate as effectively as possible." "136 And, as he noted a year later, "This amounts to the following injunction: when in doubt, allocate the cost to the party who can most cheaply enter into transactions to rectify an error." 137 In setting forth this prescription, Calabresi was stating, for the first time, the idea that has become known as the "normative Coase theorem," which holds that one should "structure the law so as to remove impediments to private agreements." "And so once again we find Calabresi willing to countenance the idea that markets will indeed resolve these problems in efficiency-enhancing (if not globally efficient) fashion if transaction costs do not-or are not allowed to-get in the way.

These twin beliefs in the correctness of the Coase theorem and the ability of parties to negotiate efficiency-enhancing agreements in certain instances did not, however, put Calabresi in the Coase theorem-true believer category. Indeed, he had little patience for those who would claim a presumption in favor of the Coase theorem when it came to practical matters of law, as we can see from his discussion of medical malpractice in the late 1970s. Here, Calabresi noted that there is no role for malpractice law "if one believes that negotiations as to appropriate treatment occur between doctors and patients with sufficient

134. Calabresi, Wonderful World, supra note 40. This statement also brought the word "Coasian" into the lexicon.

135. As Calabresi later noted, however, efficiency is not guaranteed even if transaction costs are low enough to facilitate bargaining to the appropriate level of deterrence, because assigning liability to the least-cost avoider in the first place would save the relevant costs of transacting. See Calabresi, Optimal Deterrence, supra note 109, at 659.

136. Calabresi, Changes for Automobile Claims?, supra note 38, at 608.

137. Guido Calabresi, Does The Fault System Optimally Control Primary Accident Costs?, 33 LAW \& CONTEMP. PROBS. 429, 447 (Summer 1968).

138. Robert COOTER \& ThOMAS ULEN, LAW AND ECONOMICS 89 (2d ed. 1997). 
parity of knowledge of risks." 139 This area, he said, "seems particularly appealing" for those predisposed to the Coase theorem's applicability because transaction costs, "which frequently make the pure market a poor road to an utilitarian's heaven," seem to be absent. ${ }^{140}$ The cost of establishing a market, on which Calabresi placed so much emphasis, is nonexistent. There are no large classes of potential injurers and potential victims to assemble, because the potential injurer is sitting right there in the examining room with the potential victim. ${ }^{141}$ But this, said Calabresi, is little more than "a parody of the market ideologue's dream of utilitarian efficiency in medical care." ${ }^{142}$ The problem in this instance is "parity of knowledge" the victim and informed consent is costly. As a result, far from being costless, "the medical malpractice problem [is] far more complicated than the analogous problem of knowledge in other contractual situations" and thus far removed from the realm of the Coase theorem's applicability. ${ }^{144}$

Calabresi considered Coase's University of Chicago colleague George Stigler an excellent example of the view that there should be a presumption in favor of the Coase theorem. Referencing Stigler's discussion of the Coase theorem in The Theory of Price ${ }^{145}$ - which is where Stigler gave Coase's result the name that has stuck with it to this day-Calabresi and Bobbitt argued that "[t]hough he notes that transaction costs may occasionally require state intervention, George Stigler describes the Coase theorem as generally suggesting that the "manner in which the law assigns liability will not affect the relative private marginal costs of production,' so that ... it does not matter" on which party liability rests. ${ }^{146}$ Because of this, they contended, Stigler's position was that the Coase theorem "counsels abstention" from nonmarket remedies such as government regulation. ${ }^{147}$ But in a nifty turn, Calabresi and Bobbitt continued by pointing out that "[i]f one can assume costless markets in one's theories, one can assume as well costless, perfect nonmarket approaches." ${ }^{148}$ Thus, in a Coase-theorem world, the market has nothing on government; either one can take us to nirvana. In reality, of course, both markets and governments are costly and imperfect, meaning that "the engaging question must be which in fact costs more to establish in a particular situation and who bears the cost under each of the two approaches." ${ }^{149}$

139. Guido Calabresi, The Problem of Malpractice: Trying to Round Out the Circle, 27 U. TORONTO L.J. 131, 131-32 (1977).

140. Id. at 132 .

141. Id.

142. Id.

143. Id.

144. Id. (illustrating Calabresi's more expansive definition of transaction costs).

145. STIGLER, supra note 3, at 113 .

146. CALABRESI \& BOBBITT, supra note 112 , at 213 n.3.

147. Id. at 85 .

148. Id. at 213 n.4.

149. Id. 
ITALIAN CONSPIRACY: CALABRESI, PARETO, AND THE DEATH OF THE COASE THEOREM

I have observed in the foregoing discussion that Calabresi's attitude toward Coase's negotiation result evolved significantly and in several directions over the course of his career. But none of these moves had implications nearly as dramatic as his final move-to place the Coase theorem in a Paretian-efficiency framework. Calabresi's earliest discussions of the Coase theorem had painted Coase's result as one in which negotiations would lead to outcomes that minimized the costs associated with accidents. ${ }^{150}$ Here, as in his analysis of accident law generally, Calabresi implicitly adopted what economists call a Kaldor-Hicks definition of efficiency. ${ }^{151}$ Under the Kaldor-Hicks criterion, a move is considered efficiency-enhancing if the resulting gains outweigh the losses, and a given position is considered to be efficient if there is no possible move that generates gains to the winners that exceed the losses to the losers. ${ }^{152}$ In the late 1960s and early 1970s, however, Calabresi altered his approach and began to assess bargaining solutions through a different efficiency lens-the Paretian one. The Pareto criterion says that a move is efficiency enhancing only if at least one person gains from the move and no one loses, and that a particular outcome is efficient if there is no move from that position which leaves each party at least as well off as they were in the original position. ${ }^{153}$ Although there is no distinction to be made between Kaldor-Hicks and Pareto efficiency in a Coase-theorem world of zero transaction costs-a point that Calabresi later recognized-the same cannot be said for the real world of positive transaction costs. ${ }^{154}$ And, as Calabresi discussed at great length in The Pointlessness of Pareto, but also elsewhere,${ }^{155}$ the distinction is one of significant import when it comes to evaluating Coasean bargaining and to the utilization of the insights provided by the Coase theorem in the evaluation of legal rules in a world filled with frictions. ${ }^{156}$

Calabresi's evolution from Kaldor-Hicks to Pareto can be seen in his 1968 correction of his earlier critique of the Coase theorem. Here, Calabresi defined a misallocation not as a failure to, for example, minimize costs (a Kaldor-Hicks

150. See supra Part II.B.

151. See, e.g., Calabresi, Wonderful World, supra note 40; Calabresi, The Decision for Accidents, supra note 34.

152. See, e.g., Roger E. Backhouse, The Ordinary Business of Life: A History of ECONOMICS FROM THE ANCIENT WORLD TO THE TWENTY-FIRST CENTURY 279-80 (2002).

153. Kaldor-Hicks efficiency does not mandate that compensation be paid to those who would be made worse off by the move in question. Id. It is only when such compensation actually is paid that the move in question satisfies the Pareto criterion. Id. This makes the Pareto criterion more restrictive than Kaldor-Hicks as a welfare measure.

154. Guido Calabresi, The Pointlessness of Pareto: Carrying Coase Further, 100 YALE L.J. 1211, 1222 (1991) [hereinafter Calabresi, The Pointlessness of Pareto]. If transaction costs are zero, the compensation payments necessary for the satisfaction of the Pareto criterion can be costlessly arranged.

155. See, e.g., CALABRESI \& BOBBITT, supra note 112, at 83-85.

156. Calabresi, The Pointlessness of Pareto, supra note 154, at 1223. 
notion), but rather as a situation where "there is available a possible reallocation in which all those who would lose from the reallocation could be fully compensated by those who would gain, and, at the end of this compensation process, there would still be some who would be better off than before." ${ }^{157}$ This, of course, is a classic Paretian exposition, ${ }^{158}$ and the implication, as Calabresi pointed out, is that "there is a misallocation when a situation can be improved by bargains." ${ }^{159}$ But this is where Coase's analysis provides a path to efficiency, at least in theory: "If people are rational, bargains are costless, and there are no legal impediments to bargains," said Calabresi, "transactions will ex hypothesis occur to the point where bargains can no longer improve the situation; to the point, in short, of optimal resource allocation." ${ }^{160}$

It is important to take note of the contrast between Calabresi's stance here and Coase's own 1960 emphasis on the outcome "which maximises the value of production." Paretian conception of efficiency, but with one having more of a Kaldor-Hicks or wealth-maximization flavor. Indeed, this is the criterion that had informed Coase's earlier work in the realm of welfare theory, ${ }^{162}$ which he utilized in his examples in The Problem of Social Cost, and whose implications he defended in his few subsequent commentaries on the Coase theorem. ${ }^{163}$ That said, Calabresi was by no means the first or the last to read the Coase theorem through Paretian lenses ${ }^{164}$ Coase's own wealth-maximization approach notwithstanding. Why Calabresi began to do so at this point is unclear, ${ }^{165}$ and he made little of the implications of this analysis until some two decades later. ${ }^{166}$ But if, as I have already noted, the efficiency criterion employed does not matter in a Coasetheorem world, why is Calabresi's Paretian turn of any interest or import? Three reasons can be suggested.

First, from a pure Coase-theorem perspective, it is the Paretian framework that renders the theorem tautological. Once bargaining has ceased, the result must be optimal by definition; if welfare-improving bargains were possible, they

157. Calabresi, Transaction Costs, supra note 65 , at 68.

158. Although one could interpret Calabresi's statement in Kaldor-Hicks terms, it is clear from the context of his discussion that Calabresi is speaking in terms of compensation actually being paid, per the Paretian conception.

159. Calabresi, Transaction Costs, supra note 65, at 68.

160. Id.

161. Coase, The Problem of Social Cost, supra note 1, at 8.

162. See, e.g., R.H. Coase, The Marginal Cost Controversy, 13 ECONOMICA 169 (1946) (containing Coase's analysis of pricing regulation for natural monopoly).

163. See, e.g., COASE, Notes, supra note 2.

164. This trend began with Buchanan and Stubblebine's classic article Externality and soon became commonplace. See James M. Buchanan \& Wm. Craig Stubblebine, Externality, 29 ECONOMICA 371 (1962).

165. Calabresi himself is unsure why he made this move. E-mail from Guido Calabresi, Senior Judge, U.S. Court of Appeals for the Second Circuit and Sterling Professor Emeritus of Law, Yale Law Sch., to author (Oct. 12, 2012, 8:24 AM) (on file with author).

166. One exception to this is his discussion in Tragic Choices. See CALABRESI \& BOBBITT, supra note 112 , at $85-86$. 
would be (or would already have been) consummated. ${ }^{167}$ Kaldor-Hicks efficiency, or wealth maximization, has no such implications. The problems with putting Coase's negotiation result in a Paretian context, however, go well beyond the tautology issue: It effectively destroys the Coase theorem as typically conceived-indeed, as a theoretical construct of any interest at all. The theorem tells us that an efficient and invariant result will be achieved in a world of zero transaction costs. The implication, though, is that efficiency is anything but guaranteed when transaction costs are positive. But as Calabresi recognized in 1991, it is equally true that Pareto efficiency will obtain in any state of the world. ${ }^{168}$ To put it in his 1968 language, transactions will always, even when transaction costs are positive, "ex hypothesis occur to the point where bargains can no longer improve the situation; to the point, in short, of optimal resource allocation." ${ }^{169}$ Thus, the Coase theorem's assumptions about costless transacting are not required; parties will negotiate all mutually beneficial improvementsall those for which the benefits outweigh the costs, including the costs of transacting. Moreover, any existing transaction costs or other impediments to bargaining are themselves Pareto optimal; otherwise, steps would have been taken to remove them. ${ }^{170}$ In short, what is, is efficient, and the Coase theorem's efficiency proposition does not require that we make any assumptions regarding the magnitude of transaction costs.

The adoption of the Paretian-efficiency framework, though, has a second important and related effect: It alters the nature of the invariance argument. In Coase's framework in The Problem of Social Cost, there exists a unique wealthmaximizing result, $Q^{*}$. Likewise, Calabresi had assumed, in his discussions of accident law, that there exists a unique cost-minimizing allocation. Invariance, then, obtains only if the actual outcome is $Q^{*}$ independent of the initial assignment of rights. In such a world, the Coase theorem tells us that the level of deterrence activity, the presence or absence of fencing between farmers and cattle ranchers, the amount of pollution and of various types of pollutiongenerating factories or products, and so forth, are all invariant across alternative assignments of rights.

In the Paretian context, however, the situation is altered. There is no metric for comparing one result with another-each is equally good if the gains from trade have been exhausted. Furthermore, it is almost trivial to construct a scenario in which the actual outcome is dependent on the assignment of rights, as economist F.T. Dolbear showed in $1967 .{ }^{171}$ The error of the invariance thesis

167. Calabresi, of course, made the tautology argument in force in his 1968 article; interestingly, though, he did not explicitly link back to this tautology discussion in The Pointlessness of Pareto, in spite of the fact that his 1991 analysis made the tautology argument with even greater force, and more expansively. See Calabresi, The Pointlessness of Pareto, supra note 154, at 1222.

168. See id. at $1215-16$.

169. Calabresi, Transaction Costs, supra note 65 , at 68.

170. Calabresi, The Pointlessness of Pareto, supra note 154, at 1216.

171. See F. Trenery Dolbear, Jr., On the Theory of Optimum Externality, 57 AM. ECON. REV. 90 (1967). 
in a Paretian system is so obvious that Calabresi's move to the Pareto criterion led him, rather charitably, to absolve Coase from responsibility for this proposition: "Some confusion arose," said Calabresi, "because Coase seemed to say that whatever the starting points, absent transaction costs, the same end point would be reached.... What Coase (and his followers) clearly meant, however, was that, absent transaction costs, an equally efficient point would be reached regardless of starting points." ${ }^{172}$ But this reading of Coase, though favorable, is inaccurate. Coase, like the early Calabresi ${ }^{173}$ spoke in terms of identical, not simply identically efficient, outcomes, as did the majority of Coase's followers-particularly within the Chicago law-and-economics tradition, with its wealth-maximization norm. If Coase had been working in a Paretian context, he may well not have made the error of claiming invariance. But he was working in a wealth-maximization framework and the invariance claim-in terms of identical outcomes-is both explicit in his discussion and of significant import for the point he was making.

A third byproduct of adopting the Paretian framework is the invalidation of the so-called normative Coase theorem. ${ }^{174}$ Though Calabresi had played no small part in introducing this idea into the economic analysis of law in the late 1960s, we find him arguing a very different line in 1991. "Some," Calabresi asserted, "say that if transaction costs keep us from making Pareto-superior moves, we should remove the impediments to transactions. We should, for example, implement legal changes that foster inexpensive negotiations and markets. Such changes, they argue, will lead to Pareto improvements." ${ }^{175}$ Of course, this "[s]ome" included the early Calabresi! But Calabresi circa 1991 saw the matter very differently. Someone, and perhaps many someones (and not necessarily the parties directly involved in the dispute in question), he pointed out, will lose from the process of removing these impediments to negotiation; if this were not the case, the impediments would have already been removed. ${ }^{176}$ Thus, it may be that removing impediments to bargaining will be wealth enhancing in a Kaldor-Hicks sense, but such moves create both winners and losers, meaning that they cannot be Pareto superior. ${ }^{177}$

Although Calabresi's Paretian turn had dire implications for judicial attempts to mimic the market, proponents of regulatory remedies did not escape unscathed. This same reasoning, as Calabresi emphasized, applies to any government action targeted at promoting efficiency: "It is no use," he argued, "to say that, when transaction costs keep us from achieving a state in which some are better off and none worse off, we should use 'non-market methods' to

172. Calabresi, The Pointlessness of Pareto, supra note 154, at 1215 n.12.

173. As noted above, Calabresi dropped the invariance thesis from his statements of the Coase theorem in the mid-1970s. See supra text accompanying note 114.

174. See supra text accompanying note 138 .

175. Calabresi, The Pointlessness of Pareto, supra note 154, at 1220.

176. See id.

177. Id. 
reach that position." 178 Though it may appear that nonmarket forms of organization offer a lower-cost alternative when transaction costs are high, the fact is that "[i]f we knew of and had available to us a nonmarket method that is ex ante Pareto superior, we would already have used it!" "179 If a nonmarket method has not emerged, then, it must be the case that some agents perceive that they would lose under such a method. ${ }^{180}$

Thus, both those policies favored by Coase theorem-loving advocates of market solutions and those favored by advocates of, for example, direct government regulation fail the Pareto test, as a result of which Calabresi asserted that the Pareto criterion cannot "be of any real guidance" when it comes to legal issues. ${ }^{181}$ This, for Calabresi, reflects "[t]he essence of Coase's insight" in The Nature of the Firm and The Problem of Social Cost-the idea that "transaction costs are no different from any other costs" and, as such, play a role in defining the Pareto frontier. ${ }^{182}$ Calabresi had arrived at a point, then, where the Coase theorem was anything but a magic elixir, and instead "reveals the bankruptcy of the neoclassical welfare economics' Pareto standards as guides for policy making." 183 We are left, in the end, with a "Calabresi theorem," the message of which is that what is, is efficient. ${ }^{184}$

Calabresi the "economist" had thus put himself in an interesting position. Having eschewed Kaldor-Hicks in favor of Pareto, and having shown that the Pareto criterion fails as a guide to policy, he was left, and left us, without any operational method for making the efficiency judgments that are at the heart of welfare economics - that are, indeed, the only arrow in the economist's welfare quiver. As Calabresi realized, there was only one direction in which to move: The inability of the Pareto criterion to provide any guidance for policy "makes inevitable a thoroughgoing and open discussion of distribution and of interpersonal comparisons." 185 This, of course, takes the economist into territory that is both unfamiliar and unsettling. But it also took Calabresi far from the least-cost avoider arguments that had been central to his analysis of tort law.

In a curious way, all of this brought Calabresi back to the same position in which he had been in 1968-though perhaps without realizing it. For, in spite of the tendency to associate the Coase theorem with the market-oriented wealthmaximizing metric of Chicago, the theorem plays into the hands of the more distributionally concerned New Haven. ${ }^{186}$ Indeed, the world of the Coase

178. Id.

179. Id. Calabresi saw this insight as a consequence of Coase's analysis in The Nature of the Firm. See R.H. Coase, The Nature of the Firm, 4 ECONOMICA 386 (1937).

180. Calabresi, The Pointlessness of Pareto, supra note 154, at 1220.

181. Id. at 1224; see also id. at 1218-20.

182. Id. at 1218. The Pareto frontier shows the set of Pareto-efficient points that are attainable.

183. CALABRESI \& BOBBITT, supra note 112 , at 85.

184. See Calabresi, The Pointlessness of Pareto, supra note 154, at 1212.

185. Id. at 1224 .

186. The distributional concerns of the New Haven approach to law and economics carry forward an important aspect of the legal-realist tradition at Yale. On this tradition, see, for example, LAURA 
theorem is "the best of all possible worlds" for those concerned with distributional issues. ${ }^{187}$ There is no equity-efficiency tradeoff, no "leaky bucket." For New Haven, the Coase theorem tells us that we need not sacrifice efficiency to indulge distributional preferences or goals: No matter how rights are assigned and thus no matter how distributional goals inform the assignment of rights, the allocation that results will be efficient. New Haven can thus beat Chicago at its own game. Posner's arguments about the lack of legitimacy underpinning any particular notion of justice, morals, and so on, and his pragmatist defense of the efficiency criterion as the appropriate goal for law become moot points in a Coase-theorem world, because efficiency is guaranteed. $^{188}$

As Calabresi showed in 1991, however, the Pareto criterion has nearly identical implications for a world of positive transaction costs: All equilibria are efficient and strictly noncomparable, meaning that distributional considerations involve no efficiency-related sacrifices. Once again, Calabresi and New Haven have the upper hand. Ironically, though, one could apply the same argument to support Blum and Kalven's social-insurance tort scheme ${ }^{189}$ or to any of the several other approaches to tort liability against which Calabresi leveled (Kaldor-Hicks) efficiency-based critiques over the years. Moreover, assessing transaction cost-reducing moves is not an efficiency-related exercise, but instead requires distributional judgments as between winners and losers and, where multiple transaction cost-reducing options exist, as between different groups of winners and losers.

The adoption of the Pareto criterion thus had the effect of facilitating Calabresi's distributional turn. When wealth maximization is the goal, distribution is an alternative to efficiency and at times competes with it. Under the Pareto criterion, in contrast, the choice is ultimately about which efficient outcome we desire and the normative basis for such choices. In the end, then, the Coase theorem, read through Calabresian lenses, reinforces the importance of distributional considerations and the value judgments that underlie them. And so Calabresi had, via Coase, come round full circle to his legal-realist roots. ${ }^{190}$

VIII

CONCLUSION

When Duncan Kennedy recently suggested that, up to the mid-1970s, only Calabresi and Posner were "percolating" the Coase theorem "in mainstream

Kalman, Legal Realism AT Yale, 1927-1960 (1986); Laura Kalman, Some Thoughts on Yale and Guido, 77 LAW \& CONTEMP. PROBS., no. 2, 2014 at 15, 20-21.

187. VOLTAIRE, supra note 57.

188. See Richard A. Posner, Frontiers of Legal TheOry (2001).

189. See Blum \& Kalven, Public Law Perspectives, supra note 40, at 674.

190. See supra Part I. 
legal academia, ${ }^{, 191}$ he overlooked a vast literature that saw lawyers at leading law schools probing the implications of Coase's insight for the evaluation of legal rules. ${ }^{192}$ That said, there can be no question that Calabresi deserves much of the credit-or perhaps, in the eyes of some, the blame-for putting the Coase theorem on the map of the legal community.

The Coase theorem was a useful weapon in Calabresi's crusade to replace the fault system with a market-based system of deterrence. It showed the conditions under which the market could efficiently accomplish such deterrence, and the real-world impediments to the accomplishment of the results contemplated by the Coase theorem provided Calabresi with a blueprint for factors that should be taken into account in devising a system to properly allocate costs in a world of imperfect markets. By the end of the 1960s, Calabresi was a committed believer in the theorem's logic and utility, even if equally convinced of its limited direct real-world applicability. Equally important, he "understood that Coase's insight was not an ideological insight, but rather a purely scholarly one." 193

Calabresi's 1968 article on the Coase theorem stands out as the first in the literature-either legal or economic - to realize what the Coase theorem was really all about. Calabresi said, in essence, "This is how the magical world works. It is not a tool for direct application, but a fiction." As I have already detailed, however, for Calabresi it was a useful fiction, or model, in spite of its unrealism. As he has recently noted,

Model-making is useful because it spins out boxes. Then the question becomes, "Are the boxes full, or are the boxes empty?" A model may point to something that is of no use at all. Making a model, the simplest model, like the one I used in the Cathedral article, says, "Here is a box. Gee, that is interesting, there is a box there. Is there anything in the real world that fills that box?" If there isn't, one can throw the model out. But the model may well cause one to see something that the canonical way of looking at things has caused one to miss. ${ }^{194}$

And the Coase theorem did exactly this for Calabresi, which explains why he returned to it time and again over the course of his career.

Calabresi's original attraction to Coase's insight no doubt was sparked by the correspondence that he saw between it and the established economic theory pertaining to what he called the (preexisting) bargaining case. As his understanding of the theorem evolved, however, so too did his sense for why it was useful - a sense that increasingly converged toward Coase's larger message in The Problem of Social Cost and away from the silliness that makes up so much of the commentary, pro and con, on the Coase theorem: "Like the physicist's assumption of no friction or Say's law in macro-economics," said Calabresi and Melamed, "the assumption of no transaction costs may be a useful starting point, a device which helps us see how, as different elements

191. HACKNEY, supra note 95, at 22.

192. See Medema, Debating Law's Irrelevance, supra note 5.

193. Calabresi, Neologisms Revisited, supra note 10, at 738.

194. Id. at $752-53$. 
which may be termed transaction costs become important, the goal of economic efficiency starts to prefer one allocation of entitlements over another. ${ }^{195}$ For the early Calabresi, at least, this pointed toward the mimic-the-market criterion and the normative Coase theorem. And while Calabresi was eventually to throw all of this in the dustbin as part of his embrace of Pareto, the place of the Coase theorem and its normative corollaries in the economic analysis of law was long since secured-ironically, in no small part due to Calabresi's efforts.

195. Calabresi \& Melamed, supra note 111, at 1096. 